2. Boiko O. P., Harkusha V.V. Zakharko, A. V. Kryminalnyi protses. (2017). [pidruchnyk u 2 ch. / [avt. kol. A. H. d-r yuryd. nauk, dots. O. F. Kobzar] Dnipro : Dniprop. derzh. un-t vnutr. sprav ; Lira LTD, Ch. 1. (in Ukraine).

3. Polianskyi N. N. (1956). Voprosы teoryy sovetskoho uholovnoho protsessa. M. : MHU (in Russia).

4. Kelman M. S., Murashyn O. H. (2005). Zahalna teoriia derzhavy i prava : pidruchnyk. Kyiv : Kondor (in Ukraine)

5. Nalyvaiko L. R. (2016) Teoriia i praktyka pravozastosuvannia konspekt lektsii. Dnipro: DDUVS (in Ukraine)

6. Kryminalnyi protsesualnyi kodeks Ukrainy : Zakon Ukrainy № 4651VI (2012). Verkhovna Rada Ukrainy : [sait]. URL: https://zakon.rada.gov.ua/ laws/show/4651-17\#Text

7. Kryminalnyi kodeks Ukrainy : Zakon Ukrainy № 2341-III (2001) Verkhovna Rada Ukrainy : [sait]. URL: https://zakon.rada.gov.ua/laws/ show/2341-14\#Text

8. Konstytutsiia Ukrainy : pryiniata na piatii sesii Verkhovnoi Rady Ukrainy (1996). Verkhovna Rada Ukrainy : [sait]. URL: https://glavcom.ua/news/ za-kilkistyu-zvernen-do-jespl-ukrajina-posidaje-tretje-misce--655957.html
9. Zhdyniak N. P. (2012) "Realizatsiia" ta "zastosuvannia" zaboroniaiuchykh kryminalno-pravovykh norm: spivvidnoshennia poniat. Forum prava : elektron. nauk. fakhove vyd. № 1. p. 300-306.

10. Velykyi tlumachnyi slovnyk suchasnoi ukrainskoi movy / [uklad. i holov. red. V. T. Busel] (2002) Kyiv; Irpin : Perun, 2002. (in Ukraine)

11. Tsvik V.M Petryshyn O. V. (2009) Zahalna teoriia derzhavy i prava : pidruchnyk dlia studentiv yuryd. vyshch. navch. zakl. za red. d-ra yuryd. nauk, prof., akad. APrN Ukrainy V.M. Tsvika, d-ra yuryd. nauk, prof., akad. APrN Ukrainy O. V. Petryshyna. Kharkiv : Pravo (in Ukraine)

12. Rabinovych P. M. (2001) Osnovy zahalnoi teorii prava ta derzhavy : navch. posib. [5-te vyd., zi zmin.]. Kyiv : Atika (in Ukraine).

13. Serdiuk I. A. (2016) Akt bezposerednoi realizatsii norm prava: poniattia, osoblyvosti ta vydy. Visnyk Luhanskoho derzhavnoho universytetu vnutrishnikh sprav imeni E. O. Didorenka. № 2. URL: https://search.ukr.net/ ?q=aktы\%20realyzatsyy\%20norm\%20prava\#gsc.tab=0\&gsc.q=aktы $\% 20$ rea lyzatsyy\%20norm\%20prava\&gsc.page=1

Received: 07/06/2021 1st revision: $01 / 07 / 2021$ Accepted: $20 / 07 / 2021$

O. Oliinyk, Dr. Sc. (Law), Prof., Associate Prof.

Taras Shevchenko National University of Kyiv, Kyiv, Ukraine

\title{
IMPLEMENTATION AND CONTENT OF PRINCIPLES IN ACTS OF APPLICATION AND IMPLEMENTATION OF CRIMINAL LAW
}

The purpose of the article is to determine the forms of implementation of the principles of criminal law in the acts of criminal law. Methods. Methodological tools are selected in accordance with the purpose, specifics of the object and subject of the research. The general dialectical method of scientific knowledge of real legal phenomena is viewed as the main one among other methodological tools. Special research methods used in the study are: the method of systematic analysis, formal legal, interpretation of law, comparative law and modelling methods. The theoretical basis of the study is the latest scientific works in the chosen field of research. Results. As proved during the analysis of law enforcement acts, criminal law principles have their reflection and content in the acts of application and implementation of criminal law. Each individual act of application or implementation of criminal law takes into account the relevant set of principles that complement each other and provide law enforcement agencies with comprehensive tools to reflect in such acts of objectively existing social relations. Acts of implementation of the rules of criminal law are "manifestations" of the actual behaviour of the subjects of criminal law. Conclusions. According to the results of the study, each individual act of application or implementation of criminal law takes into account the relevant set of principles that complement each other and provide law enforcement agencies with comprehensive tools to reflect in such acts of objectively existing social relations. These are the acts of application of criminal law that embody the greatest number of principles of criminal law mainly due to the reflection of the latter in the documents drawn up by law enforcement agencies (indictments, petitions for coercive measures of medical or educational nature, convictions, rulings, etc.).

Keywords: principles of criminal law; acts of implementation of criminal law; acts of application of criminal law.

Bulletin of Taras Shevchenko National University of Kyiv. Legal Studies, 2021; 3 (118): 80-85

УДК 347.51

DOI: https:doi.org/10.17721/1728-2195/2021/3.118-15
ISSN 1728-2195

(c) Taras Shevchenko National University of Kyiv, Publishing center "Kyiv University", 2021

О. О. Отраднова, д-р юрид. наук, проф. Київський національний університет імені Тараса Шевченка, Київ, Україна ORCID ID: 0000-0002-4206-8412

\section{РОЗВИТОК ШКОЛИ ДЕЛІКТНОГО ПРАВА В УНІВЕРСИТЕТІ СВЯТОГО ВОЛОДИМИРА - КИЇВСЬКОМУ НАЦІОНАЛЬНОМУ УНІВЕРСИТЕТІ IMЕНІ ТАРАСА ШЕВЧЕНКА}

Досліджено розвиток наукової школи деліктного права в Київському національному університеті імені Тараса Шевченка. Метою дослідження є аналіз розвитку вказаної наукової школи та виявлення основних тенденцій і ключових напрямів такого розвитку.

Під час проведення дослідження використано такі методи: історико-правовий, аналізу та синтезу, філософські методи (діалектичний, герменевтичний), загальнонаукові (системний, структурно-функціональний), а також загальнологічні методи (аналізу та синтезу, індукції, дедукції й аналогії, абстрагування, узагальнення, формалізації, моделювання).

Проблематика цивільно-правових деліктів цікавила вчених наукової школи Київського університету в усі часи, хоча глибина інтересу та напрями досліджень на різних етапах історичного розвитку відрізнялися.

У період до революції 1917 р. дослідники здебільшого розглядали делікти як різновид цивільно-правових зобов'язань і винагороди за заподіяну шкоду. Бачення делікту як виду цивільно-правової, позадоговірної відповідальності в ті часи відсутнє.

Радянський період розвитку школи деліктного права Київського університету характеризувався зміною вектора дослідження. Цивільний делікт почав розглядатися здебільшого не як зобов'язання, а як відповідальність. Саме у ті часи з'явився підхід до визнання єдиною підставою деліктної відповідальності складу цивільного правопорушення.

Період незалежної України породив плеяду нових учених, науковим інтересом яких були іє цивільно-правові делікти. Сучасна доктрина стала відходити від розуміння делікту як відповідальності, повертаючись до дослідження відикодування позадоговірної шкоди як цивільно-правового зобов'язання. Крім того, дослідники сучасного періоду дивляться на проблематику деліктів ширше - через аналіз механізму його правового регулювання.

Також сучасний період розвитку школи деліктного права Київського національного університету імені Тараса Шевченка характеризується значною увагою до нових сфер заподіяння шкоди, зокрема проблеми компенсації моральної шкоди, відшкодування шкоди, заподіяної державою у цілому та окремими державними інституціями зокрема, відшкодування шкоди, заподіяної дефектами продукції із фокусом на цифрову продукцію тощо.

Ключові слова: делікт, цивільно-правова відповідальність, відшкодування шкоди, історія правових досліджень, наукова школа.

\section{ВСТуп}

Школа права Університету Святого Володимира Київського національного університету імені Тараса Шевченка $є$ однією з найстаріших і найпотужніших наукових юридичних шкіл України. Науковий інтерес пред- ставників школи розповсюджувався та розповсюджується майже на всі галузі сучасного матеріального і процесуального права, міжнародне та європейське право, а також римське право. 
Одним із важливих напрямів, який майже в усі часи розвивався у Київському університеті, $є$ дослідження відшкодування позадоговірної шкоди або цивільноправові делікти. Цей напрям є старим як римське право та новітнім як комп'ютерні технології. Адже на будьякому етапі людського розвитку існували, існують і будуть існувати ситуації заподіяння однією особою іншій шкоди поза межами цивільно-правового договору. I саме дослідники Київської школи права майже завжди були активними учасниками наукових дискусій, а часто і "законодавцями мод" у сфері цивільно-правових деліктів. В усі часи вони займалися найактуальнішими питаннями відшкодування позадоговірної шкоди. Саме представнику київської школи Г. К. Матвєєву належить ґрунтовне дослідження вини як підстави цивільно-правової відповідальності, а також загальна ідея складу цивільного правопорушення як підстави цивільно-правової відповідальності. Саме у Київському університеті розроблялося вчення про механізм цивільно-правового регулювання деліктних зобов'язань. Саме у цій науковій школі проводяться цікаві дослідження актуальних і сучасних проблем відшкодування позадоговірної шкоди (компенсація моральної шкоди, відшкодування шкоди, заподіяної державою, зокрема й органами судової влади, відшкодування шкоди, заподіяної дефектами продукції, у тому числі цифрової продукції, тощо. Саме тому дослідження розвитку школи деліктного права Київського університету імені Тараса Шевченка $є$ актуальним і може надихнути майбутніх дослідників на нові наукові пошуки.

Метою дослідження $є$ проведення аналізу розвитку наукової школи деліктного права у Київському університеті імені Тараса Шевченка та виявлення основних тенденцій і ключових напрямів такого розвитку.

Об'єктом дослідження $є$ наукові пошуки у сфері деліктного права вчених Університету Святого Володимира у період до 1917 р., радянських учених Київського державного університету імені Тараса Шевченка та сучасних дослідників цього університету.

Під час проведення дослідження використано історико-правовий метод (для вивчення наукових робіт учених минулих років), методи аналізу та синтезу (для визначення особливостей наукової школи деліктного права на різних етапах розвитку суспільства. Також під час дослідження застосовано філософські (діалектичний, герменевтичний), загальнонаукові (системний, структурнофункціональний), а також загальнологічні методи (аналізу та синтезу, індукції, дедукції й аналогії, абстрагування, узагальнення, формалізації, моделювання).

\section{ОСНОВНА ЧАСТИНА}

Цивільно-правова деліктологія в університеті Святого Володимира до революції 1917 р. Цивілістична наука дореволюційного періоду ґрунтувалася на ретельному вивченні римського права, яке розглядалося як теоретична основа права цивільного. На юридичному факультеті Університету Святого Володимира із самого початку його створення існували кафедра римського права та кафедра російських цивільних законів. Професори Університету Святого Володимира приділяли багато уваги викладанню римського приватного права і проведенню наукових досліджень у цій ссрері. У цілому слід зазначити, що праць, присвячених проблемам цивільно-правових деліктів у той період було небагато. Більше уваги приділялося дослідженню інших інститутів римського та цивільного права. Разом із тим певні праці з питань цивільних деліктів побачили світ у Київському університеті. 1907 р. опубліковано роботу Т.М. Яблочкова "Понятие вины в римском праве (Черты индивидуализма в учениях римских юристов о вине)" [1]. А 1910 р. Т. М. Яблочков у Київському університеті захистив магістерську дисертацію. Його робота мала назву "Влияние вины потерпевшего на размер возмещаемых ему убытков. Часть теоретическая" [2]. Значну частину її змісту присвячено саме аналізу вини у римському приватному праві; решта - оцінюванню проблематики вини потерпілого у цивільному праві.

Серед небагатьох друкованих праць дореволюційного періоду, присвячених власно деліктним зобов'язанням, можна згадати доповідь Й. О. Покровського "Обязательства из деликтов в проекте Гражданского уложения", яка була прочитана на зборах Київського юридичного товариства 27 листопада 1899 р., а її друкований варіант став додатком до протоколів зборів Київського юридичного товариства за 1899 р. Й. О. Покровський аналізує статті "Проекту Цивільного уложення Російської імперії", присвячені "винагороді за шкоду, заподіяну недозволеними діяннями", приділяючи увагу умовам виникнення деліктного зобов'язання, таким як: наявність шкоди, недозволене діяння, причинний зв'язок між діянням і шкодою та вина (умисел або необережність особи, що заподіяла шкоду), а також умовам звільнення від обов'язку відшкодування позадоговірної шкоди [3].

У цілому публікації вчених університету Святого Володимира з питань деліктного права відображали загальну тенденцію тих років - цивільно-правові делікти сприймалися як винагорода за заподіяну шкоду, а не як різновид цивільно-правової відповідальності. Останній підхід прийшов у цивілістичну доктрину дещо пізніше - у радянський період, а точніше - після Другої світової війни.

Радянський період розвитку школи деліктного права в Київському університеті. Поступ школи деліктного права в Київському університеті в радянський період у цілому відображав загальні тенденції розвитку радянської деліктології. У перші роки після революції 1917 р. приватно-правові делікти не були пріоритетною темою для радянських юристів, адже на порядку денному стояла розбудова нової держави.

Перші праці з проблем відшкодування позадоговірної шкоди почали з'являтися у 20-30-х роках XX сторіччя після прийняття першого радянського Цивільного кодексу 1922 р. Тоді побачили світ публікації Я. М. Магазинера "Ответственность государства за причиненный вред" [4], К. М. Варшавського "Обязательства, возникающие вследствие причинения вреда другому лицу", 1929 р. [5], К. К. Яічкова "Обязательства из причинения вреда" 1939 р. [6] та ін.

Однак розквіт науки радянського деліктного права прийшовся вже на повоєнний період. І значною мірою цей розвиток обумовлений результатами досліджень учених Київського університету, який у ті часи вже носив ім'я Тараса Шевченка.

Значний вклад у науку про цивільно-правові делікти вніс відомий вчений-цивіліст Генадій Костянтинович Матвєєв. Він був переведений на роботу до Київського державного університету 1938 р. Під час Другої світової війни був мобілізований і повернувся до роботи в університеті 1946 року.

Хоча Г. К. Матвєєв за заслугами вважається одним із засновників школи міжнародного приватного права в Київському університеті, значна його увага була присвячена дослідженню цивільно-правових деліктів. 1951 р. учений захистив докторську дисертацію на тему "Вина як підстава цивільно-правової відповідальності". А 1955 р. на підставі проведеного дослідження була видана його монографрія "Вина в советском гражданском праве". Г. К. Матвєєв проводить ґрунтовний аналіз підстав відповідальності порушника і наголошує, що протиправна поведінка може тягти за собою відповідальність 
тільки за умов, коли присутні обов'язкові елементи, сукупність яких визначається як склад правопорушення: об'єктивні - протиправність, шкода, причинний зв'язок, і суб'єктивні - вина. Вина, що заподіює шкоду, є суб'єктивною підставою цивільно-правової відповідальності і разом із тим - суб'єктивним елементом складу цивільного правопорушення. Наявність цього елемента є обов'язковою, його відсутність свідчить про те, що складу правопорушення немає, а відтак не може бути, за загальним правилом, і відповідальності за заподіяну шкоду. Таким чином, Г. К. Матвєєв виступив опонентом теорії "заподіяння", обґрунтувавши інший підхід - відповідальності, заснованої на принципі вини [7].

Розпочавши з дослідження проблем вини як підстави цивільно-правової, зокрема деліктної відповідальності, у подальшому Г. К. Матвєєв приділив значну наукову увагу іншим підставам цивільно-правової відповідальності. Результатом проведеного пошуку стала відома монографрія "Основания гражданско-правовой ответственности", видана 1970 р. Г. К. Матвєєв - один із перших радянських учених, який запропонував концепцію складу цивільного правопорушення як підстави цивільно-правової відповідальності. Учений відстоював позицію, що саме склад цивільного правопорушення (за аналогією зі складом злочину у кримінальному праві) $€$ єдиною підставою цивільно-правової відповідальності. До складу цивільного правопорушення входили такі елементи: протиправна поведінка, заподіяна шкода, причинно-наслідковий зв'язок між протиправною поведінкою та шкодою й вина заподіювача (суб'єктивний елемент). І навіть, якщо йшлося про необов'язковість якогось елемента для притягнення особи до цивільноправової відповідальності (наприклад, необов'язковість вини у разі заподіяння шкоди джерелом підвищеної небезпеки), це, на думку Г. К. Матвєєва, не руйнувало склад, а лише робило його усіченим.

Концепція складу цивільного правопорушення як підстави цивільно-правової відповідальності, на довгі роки увійшла до вітчизняної правової доктрини і навіть зараз буває згадується в судових рішеннях.

Г.К. Матвєєв був успішним науковим керівником. Під його керівництвом захищено багато кандидатських і декілька серйозних докторських дисертацій. Зокрема докторські роботи під керівництвом Г. К. Матвєєва захистили Д. В. Заікіна (Боброва), В. І. Кисіль, В. В. Луць, О. А. Підопригора, 3. В. Ромовська, Я. М. Шевченко. Усі ці відомі українські вчені внесли значний вклад у вітчизняну цивілістику. Зокрема, Д. В. Боброва та Я. М. Шевченко посилили школу деліктного права Київського університету. Також питаннями деліктного права цікавився і син Г. К. Матвєєва - Юрій Геннадійович Матвєєв. 1973 р. він випустив монографрію "Англо-американское деликтное право", де розглядалися як загальні умови відповідальності за заподіяну шкоду, так і спеціальні делікти, властиві саме системі загального права (порушення володіння - trespass, перешкоджання - nuisance, недбалість - negligence).

Учениця Г.К. Матвєєва - Діна Василівна Заікіна (Боброва) весь свій науковий пошук присвятила питанням деліктного права. 1958 р. вона захистила кандидатську дисертацію на тему "Підстави та обсяг відповідальності за завдання каліцтва або смерті особи за радянським цивільним правом". А 1987 р. - докторську дисертацію на тему "Проблеми деліктної відповідальності в радянському цивільному праві". Метою дисертаційного дослідження Д. В. Бобрової було розроблення понятійного апарату концепції деліктної відповідальності, визначення шляхів підвищення попереджувально-виховної ролі деліктної відповідальності, виявлення особливостей ії підстав, розкриття специфіки необхідної оборони і крайньої необхідності як категорій цивільного права [8]. Результатом наукового дослідження стало ґрунтовне та деталізоване визначення цивільноправової деліктної відповідальності, що містило в собі всі ознаки цього правового інституту.

Під час роботи на кафедрі цивільного права Київського університету проф. Боброва вела спецкурси із проблем деліктного права та цивільно-правового регулювання недоговірних зобов'язань, керувала дипломними роботами із зазначеної тематики. Д. В. Боброва внесла значний вклад у законопроєктну роботу, беручи участь у розробленні проєкту Цивільного кодексу незалежної України.

Ще одна учениця Г. К. Матвєєва - Ярославна Миколаївна Шевченко -1959 по 1962 р. навчалася в аспірантурі юридичного фракультету Київського університету. 1964 р. під керівництвом Г. К. Матвєєва вона захистила кандидатську дисертацію на тему "Майнова відповідальність за шкоду, заподіяну дітьми". І хоча після закінчення аспірантури Я. М. Шевченко почала працювати у Секторі держави і права АН УРСР (тепер - Інститут держави і права імені В. М. Корецького НАН України), їі науковий інтерес продовжувала захоплювати проблематика цивільно-правових деліктів. 1982 р. вона захистила докторську дисертацію на тему "Теоретичні проблеми правового регулювання цивільної відповідальності неповнолітніх за правопорушення". І в подальшому Я. М. Шевченко виступала автором і співавтором численних монографій та інших наукових праць із питань цивільно-правової відповідальності неповнолітніх.

Значний вплив на розвиток учення про делікти в радянські часи мала доктрина юридичної відповідальності, що розроблялося представниками науки теорії права. Це потягнуло за собою певну трансформацію розуміння суті цивільно-правових деліктів. Так, якщо у 20-40-х рр. делікти розглядалися переважно у розумінні цивільноправового зобов'язання, яке вважалося охоронним, таким, що не має самостійної господарської функції, то в подальшому бачення делікту почало будуватися через призму цивільно-правової позадоговірної відповідальності. Відшкодування позадоговірної шкоди розглядалося здебільшого через поняття "відповідальність", яка при цьому відбувається у зобов'язально-правовій формі. Це зрештою привело до того, що у ЦК УРСР 1963 р. гл. 40 мала назву "Зобов'язання, що виникають внаслідок заподіяння шкоди", але переважна більшість статей, які входили до цієї глави, містили слово "відповідальність" [9].

Подібний підхід відобразився і у працях ученихделіктологів Київського університету. Їхні наукові роботи також стосувалися бачення відшкодування позадоговірної шкоди як виду цивільно-правової відповідальності. Тому переважно дослідження стосувалися саме аналізу підстав та умов притягнення особи до відповідальності, а меншою мірою - визначенню суб'єктів, об'єкта та змісту як елементів деліктного зобов'язання.

У пострадянський період інтерес до цивільноправових деліктів серед науковців Київського національного університету імені Тараса Шевченка значно знизився. Причиною цього була докорінна перебудова економічних і суспільних відносин, повернення до ринкової економіки, а отже і необхідність відродження та/або створення нових правових конструкцій, не властивих радянському праву. У зв'язку із цим увага вчених приділялася здебільшого питанням права власності, юридичним особам та іншим формам ведення бізнесу, новим договірним конструкціям тощо.

Одним із небагатьох, але дуже серйозних нововведень періоду "перебудови" у сфері деліктів було включення 1993 р. до Цивільного кодексу УРСР 1963 р. 
ст. 440-1, яка дозволяла відшкодування моральної (немайнової) шкоди. У ст. 440-1 зазначалося, що моральна (немайнова) шкода, заподіяна громадянину або організації діяннями іншої особи, яка порушила їхні законні права, відшкодовується особою, яка заподіяла шкоду, якщо вона не доведе, що моральна шкода заподіяна не з їі вини. Моральна шкода відшкодовується у грошовій або іншій матеріальній формі за рішенням суду незалежно від відшкодування майнової шкоди. Розмір відшкодування визначається судом з урахуванням суті позовних вимог, характеру діяння особи, яка заподіяла шкоду, фрізичних чи моральних страждань потерпілого, а також інших негативних наслідків, але не менше п'яти мінімальних розмірів заробітної плати.

Отже вперше в українському праві з'явилася законодавчо закріплена можливість компенсації моральної шкоди. I це одразу поставило перед наукою ряд серйозних питань, зокрема щодо доведення наявності моральної шкоди у потерпілого та визначення розміру відшкодування. На кафедрі цивільного права Київського національного університету імені Тараса Шевченка питаннями моральної шкоди цікавилася проф. Д. В. Боброва. Вона пропонувала цю тему для дослідження своїм учням у межах написання кандидатських дисертацій (Є. В. Солодко), дипломних, а згодом - магістерських робіт (С. В. Печенюк та ін.). Також проф. Боброва входила до складу робочої групи з підготовки проєкту нового Цивільного кодексу України, де відповідала зокрема і за зміст положень гл. 3 "Захист цивільних прав та інтересів" та гл. 82 "Відшкодування шкоди".

Сучасний період розвитку школи деліктного права в Київському національному університеті імені Тараса Шевченка. Після виходу на пенсію Д. В. Бобрової викладачем спеціальних курсів, присвячених недоговірним і деліктним зобов'язанням, на кафедрі цивільного права стала авторка цієї статті на той час доц. О. О. Отраднова. Це зумовило зміну вектора ії наукових пошуків. Якщо на етапі підготовки кандидатської дисертації О. О. Отраднова більше цікавилася проблемами договірного права та загальними положеннями про зобов'язання, то вже її докторська дисертація мала назву "Механізм цивільноправового регулювання деліктних зобов'язань".

Метою дисертаційного дослідження було визначено розроблення на основі наукового аналізу цілісної концепції механізму цивільно-правового регулювання деліктних зобов'язань, виявлення особливостей його складових для підвищення ефективності правового регулювання відшкодування позадоговірної шкоди та подальшого розвитку науки цивільного права. Як завдання дослідження передбачалося: визначити поняття та складові механізму цивільно-правового регулювання деліктних зобов'язань; дослідити особливості норм права, що регулюють деліктні зобов'язання; розкрити властивості принципів та презумпцій у системі регуляторів деліктних правовідносин; визначити підстави й умови виникнення деліктних зобов'язань; виявити особливості деліктного зобов'язання як правовідношення; розкрити шляхи реалізації суб'єктивних прав та юридичних обов'язків суб'єктами деліктного зобов'язання; надати конкретні теоретичні та практичні пропозиції і рекомендації щодо вдосконалення правового регулювання та практики захисту прав та охоронюваних законом інтересів суб'єктів деліктних зобов'язань та ін.

Крім загальних проблем цивільно-правових деліктів учених Київського університету цікавили також і проблеми окремих (спеціальних) деліктів. Причому перш за все увага зверталася та і звертається на дослідження нових і проблемних сфер відшкодування позадоговірної шкоди. Це передусім компенсація моральної шкоди, різні аспекти відшкодування позадоговірної шкоди, заподіяної державою, проблеми відшкодування шкоди, заподіяної недоліками товарів, робіт (послуг) тощо.

Так 2001 р. В. Д. Чернадчук захистив дисертацію на тему "Відшкодування моральної шкоди при порушенні трудових прав". А 2002 р. була захищена дисертація І. В. Забари "Відшкодування моральної (немайнової) шкоди в міжнародному приватному праві", де автор намагався розібратися із проблемними питаннями деліктних зобов'язань з іноземним елементом.

Перш за все йдеться про цивільно-правову відповідальність держави. Цьому питанню присвятив своє дослідження доцент Михайло Михайлович Хоменко. 2013 р. він захистив дисертацію на тему "Відшкодування шкоди, завданої органами державної влади, їх посадовими та (або) службовими особами". У роботі досліджувалися особливості та проблемні питання відшкодування шкоди державою, суб'єктний склад таких правовідносин, причини неефрективного виконання вказаних деліктних зобов'язань.

2017 р. побачило світ наукове дослідження С. В. Куліцької на тему "Зобов'язання відшкодування (компенсації) шкоди, заподіяної судом". Дисертантка поставила за завдання розкриття правової природи, сучасного стану та майбутніх перспектив зобов'язань відшкодування (компенсації) шкоди, заподіяної судом. У роботі авторка надала цікаві та корисні пропозиції щодо вдосконалення механізму відшкодування шкоди, заподіяної судом. Зокрема у дисертації обґрунтовано необхідність запровадження в Україні такого механізму відшкодування (компенсації) шкоди, який передбачав би поєднання індивідуалізації деліктної відповідальності судді (щомісячні відрахування із суддівської винагороди у розмірі фріксованих внесків, які зараховуватимуться на окремі спеціальні рахунки на ім'я кожного судді) із субсидіарною роллю держави (якщо накопичених на рахунку коштів недостатньо, належна потерпілій особі сума відшкодування виплачуватиметься з бюджетних коштів), із можливістю судді отримати винагороду у разі бездоганного виконання своїх обов'язків. Також дисертантка доводила перспективність упровадження в Україні обов'язкового державного страхування деліктної відповідальності суддів [10].

Крім того, у роботі С. В. Куліцької ретельно проаналізовано проблеми встановлення причинно-наслідкового зв'язку. Авторка пропонує застосовувати кількарівневий тест з установлення наявності/відсутності причинно-наслідкового зв'язку в деліктних зобов'язаннях: у першу чергу повинна застосовуватися теорія conditio sine qua non/"the But-For Test", після якої - один або декілька "фрільтрів" отриманих результатів (зокрема і теорія адекватного заподіяння). За необхідності, з метою подолання проблемних ситуацій, які перешкоджатимуть застосуванню виключно теорії conditio sine qua non/"the But-For Test" (наприклад, установлення причинно-наслідкового зв'язку у випадках наявності кількох самодостатніх причин настання шкоди), цей алгоритм може бути доповнено перевіркою на Necessary Element of a Sufficient Set (NESS) [10].

$\mathrm{He}$ залишалися осторонь тематики цивільноправових деліктів і процесуалісти. Так 2019 р. П. С. Захаров завершив своє наукове дослідження на тему "Доказування у справах про відшкодування шкоди, заподіяної внаслідок дорожньо-транспортної пригоди, у цивільному процесі України".

Останнім часом певний інтерес дослідників наукової школи Київського національного університету імені Тараса Шевченка викликають аспекти відшкодування шкоди, заподіяної новітніми технологіями. Ідеться про так звану 
product liability, або відповідальність за шкоду, заподіяну внаслідок недоліків товарів, робіт (послуг). Одним 3 останніх досліджень на цю тему є робота аспіранта кафедри цивільного права Д. В. Черкасова на тему "Відповідальність за шкоду, завдану внаслідок дефекту продукції". Дослідник не просто аналізує особливості суб'єктного складу, об'єктів і змісту зобов'язання з відшкодування шкоди, заподіяної дефектними товарами, роботами (послугами), але і звертає увагу на випадки заподіяння шкоди цифровою продукцією. Ще десять років потому подібні теми не могли бути предметом наукових досліджень. Але нині цифровий світ став частиною життя багатьох людей. Тому і випадки заподіяння шкоди цифровою продукцією також перестали бути чимось екзотичним. Разом із тим, правова доктрина цивільно-правових деліктів тут залишається на декілька кроків позаду, адже у цифровому середовищі не завжди спрацьовують класичні правила щодо суб'єктів цивільно-правового зобов'язання, шкоди, причинного зв'язку тощо.

\section{ВИСНОВКИ}

Проблематика цивільно-правових деліктів цікавила вчених наукової школи Київського університету в усі часи, хоча глибина інтересу та напрями досліджень на різних етапах історичного розвитку відрізнялися.

У період до революції 1917 р. дослідники переважно розглядали делікти як різновид цивільно-правових зобов'язань і винагороди за заподіяну шкоду. Бачення делікту як виду цивільно-правової, позадоговірної відповідальності у ті часи було відсутнє.

Радянський період розвитку школи деліктного права Київського університету характеризувався зміною вектора дослідження. Цивільний делікт почав розглядатися здебільшого не як зобов'язання, а як відповідальність. Деліктна відповідальність була різновидом цивільно-правової відповідальності, а та, у свою чергу різновидом юридичної відповідальності. Це послугувало тому, що дослідники тих часів, серед яких були такі відомі вчені, як Г. К. Матвєєв, Ю. Г. Матвєєв, Д. В. Боброва, Я. М. Шевченко та інші, здебільшого аналізували цивільно-правовий делікт крізь призму відповідальності, досліджуючи підстави й умови її виникнення. Саме у ті часи з'явився науковий, а згодом і практичний підхід до визнання єдиною підставою деліктної відповідальності складу цивільного правопорушення.

Період незалежної України породив плеяду нових учених, науковим інтересом яких були і $є$ цивільно-правові делікти. Сучасна доктрина стала відходити від розуміння делікту як відповідальності, повертаючись до дослідження відшкодування позадоговірної шкоди як цивільноправового зобов'язання. Крім того, дослідники сучасного періоду дивляться на проблематику деліктів ширше - через аналіз механізму його правового регулювання.

Сучасний період розвитку школи деліктного права Київського національного університету імені Тараса Шевченка характеризується також значною увагою до нових сорер заподіяння шкоди, зокрема і проблеми компенсації моральної шкоди, відшкодування шкоди, заподіяної державою у цілому й окремими державними інституціями зокрема, відшкодування шкоди, заподіяної дефектами продукції із фокусом на цифрову продукцію тощо.

\section{Список використаних джерел}

1. Яблочков, Т. М. Понятие вины в римском праве (Черты индивидуализма в учениях римских юристов о вине) / Т.М.Яблочков. Москва : Издание книжного магазина И. К. Голубева под фирмой "Правоведение", 1907. - 39 с

2. Яблочков Т.М. Влияние вины потерпевшего на размер возмещаемых ему убытков. Том 1: Часть теоретическая / Т.М. Яблочков, Приват-доцент Демидовского Юридического Лицея. - Ярославль: Типография Губернского Правления, 1910. - XII, 459 с.

3. Правова доктрина України: у 5 т. Т. 3: Доктрина приватного права України / Н.С. Кузнєцова, Є.О. Харитонов, Р.А. Майданик та ін. 760 c. - c. 316

4. Магазинер Я.М. Ответственность государства за причиненный вред (ст. 407 и 403 ГК) // Вестник советской юстиции. - Харьков. - 1926. - № 23. - с. 901.

5. Варшавский К.М. Обязательства, возникающие вследствие причинения вреда другому лицу. - М. - 1929 г. - 190 с

6. Яичков К.К. Обязательства из причинения вреда (Библиотека народного судьи и народного заседателя). - М.: Юрид. Изд-во НКЮ CCCP, 1939. - 30 c

7. Матвєєв Г.К. Вибране. Упоряд. В.І. Кисіль. - К.: Україна, 2008. 600 c. - c. 14

8. Боброва Д.В. Проблемы деликтной ответственности в советском гражданском праве. Автореф. дис. Д.ю.н. - Харьков, 1988. - с. 5.

9. Правова доктрина України: у 5 т. Т. 3: Доктрина приватного права України / Н.С. Кузнєцова, Є.О. Харитонов, Р.А. Майданик та ін. 760 с. - с. 317

10. Куліцька С.В. Зобов'язання відшкодування (компенсації) шкоди, заподіяної судом. - А-реф дис. К.ю.н. - Київ, 2017. - с. 7.

References

1. Yablochkov T.M. (1907) Poniatie viny v rimskom prave (Cherty individualizma $v$ ucheniiah rimskih juristov o vine) [The notin of fault in Roman law (the characters of individualization in Romal lawyers doctrine about the fault]. Moskva: Izdaniie knizhnogo magazina I.K. Golubeva pod firmoy Pravovedenie (in Russian).

2. Yablochkov T.M. (1910) Vliianie viny poterpevshego na razmer vozmeshchaemykh emu ubytkov. Tom 1 Chast teoreticheskaya [The influence of the victim's fault on the amount of damage compensation. Volume 1. Theoretical part]. Yaroslavl: Tipografia Gubernskogo pravleniia, 1910 (in Russian)

3. N.S. Kuzneysova, E.O. Kharytonov, R.A. Maydanyk (2013) Pravova doctryna Ukrainy. U 5 t. T 3 Doktryna pryvatnogo prava Ukrainy [Law doctrine of Ukraine in 5 volumes. Volume 3 Private law doctrine]. Kharkiv: Pravo (in Ukrainian)

4. Magaziner J.M. (1926) Otvetstvennost gosudarstva za prichinennyi vred (ct. 407 I 403 GK) [State liability for damage cause (art. 407 and 403 of Civil code)] / Vestnik sovetskoy justicii [Soviet justice review] - N 23.

5. Varshavskiy K.M. (1929) Obiazatelstva voznikajushchie vsledstvie prichinenija vreda drugomu litsu [Obligations from damage caused]. Moskva (Moskow) (in Russian).

6. Jiaichkov K.K.(1939) Obiazatelstva is prichineniia vreda (Biblioteka narodnogo sudii I narodnogo zasedatelia) [Obligations from damage caused (Library of the judge and jury. M. _Jurid izdatelstvo NKJ SSSR (in Russian).

7. Matveev G.K. (2008) Vybrane [Selected papers]. Uporiadnyk V.V. Kysyl [editor Vasyl Kysyl]. - K.: Ukraina, (in Ukrainian)

8. Bobrova D.V. (1988) Problemy deliktnoy otvetstvennosti v sovetskom grazhdanskom prave [Problems of tort liability in Soviet law] Avtoreferat dys. Doctora juridicheskih nauk [doctor of science dissertation]. Kharkov (in Russian)

9. N.S. Kuzneysova, E.O. Kharytonov, R.A. Maydanyk (2013) Pravova doctryna Ukrainy. U 5 t. T 3 Doktryna pryvatnogo prava Ukrainy [Law doctrine of Ukraine in 5 volumes. Volume 3 Private law doctrine]. Kharkiv: Pravo (in Ukrainian)

10. Kulitska S.V. [2017] Zoboviazannia vidshkoduvannia (kompensatsii) shkody, zapodiianoi sudom [Obligations of damage compensation caused by courts] - Avtoreferat dys. kandydata juridicheskih nauk [PhD dissertation]. Kyiv, Taras Shevchenko national University (in Ukrainian)

Received: $31 / 07 / 2021$ Accepted: $20 / 08 / 2021$

O. Otradnova, Dr. Sc. (Law), Prof.

Taras Shevchenko National University of Kyiv, Kyiv, Ukraine

\section{DEVELOPMENT OF THE TORT LAW SCHOOL IN ST. VOLODYMYR UNIVERSITY - TARAS SHEVCHENKO NATIONAL UNIVERSITY OF KYIV}

The paper deals with a research of Tort law school development in St. Volodymyr's University - Taras Shevchenko National University of Kyiv. The purpose of the research is to analyse the development of the Tort law school and to study the main trends and key directions of the development.

The author applied lots of different research methods, among which were historical and legal method (for the analysis of the works from the past), analysis and synthesis (for stating the peculiarities of the research approaches in different studies' periods). Also, such methods as philosophy methods (dialectic and hermeneutic), general research methods (systemic and structural-functional), general logic methods (induction and deduction, analogy, abstraction, generalization, formalization, and modelling) were used. 
The topic of civil torts was interesting for the researchers from Kyiv University law school any time while the depth of interest and research approaches differed depending on the historical period.

Before the revolution of 1917 the researchers mostly looked on the torts as on the type of civil obligation and the reward for damage caused. No one treated the torts from the standpoint of a type of civil liability at that time.

The Soviet period of the Tort law School development was characterized by a change of the research vector. The researchers started focusing on civil torts as liability rather than civil obligations. Tort liability is a type of civil liability and the latter is a type of legal liability.

That causes a regime when the researchers (some well-known names of that time are: Gennadiy Matveev, Yuriy Matveev, Dina Bobrova, Yaroslavna Shevchenko etc.) mostly analyse civil tort as a civil liability. They focused their attention on the foundations and the conditions of tort liability. Precisely at that time, the theory of "civil wrong compound" as the main foundation of civil liability appeared.

Independent Ukraine spawned a new pleiad of researchers whose research interest was civil torts. Modern civil law doctrine started refusing the understanding of civil tort as a type of civil liability. It comes back to the tort as a type of obligation. Moreover, modern researchers look on the tort's issues much wider - through the prism of legal regulation mechanism.

Constantly, modern researchers of Taras Shevchenko National University Law School pay great attention to the new topical spheres of torts, particularly to non-pecuniary damage compensation, damage compensation caused by the State and State agencies and product liability together with digital product liability.

Keywords: tort, civil liability, damage compensation, history of legal research, scientific school.

Bulletin of Taras Shevchenko National University of Kyiv. Legal Studies, 2021; 3 (118): 85-92

УДК. 347.1

DOI: https:doi.org/10.17721/1728-2195/2021/3.118-16
ISSN 1728-2195

(C) Taras Shevchenko National University of Kyiv, Publishing center "Kyiv University", 2021

Л. В. Панова, канд. юрид. наук, доц. Київський національний університет імені Тараса Шевченка, Київ, Україна ORCID ID: 0000-0002-1393-8626

\section{МЕТОДОЛОГІЧНІ ПІДХОДИ ДО ПРОБЛЕМИ ВЗАЕМОЗВ'ЯЗКУ ПРИВАТНОГО ТА ПУБЛІЧНОГО ПРАВА У РОЗРАХУНКОВИХ ВІДНОСИНАХ}

В основу дослідження покладено існуючу у правовій науці доктрину поділу права на приватне та публічне. Аналізується їі вплив на відносини, що виникають на ринках фінансових послуг. Дослідження проведено з урахуванням результатів вітчизняних і зарубіжних авторів у сфері права і у сфері економіки.

Методологічною основою дослідження є загальнонаукові та спеціальні методи пізнання.

Доводиться, що концепція поділу права на приватне та публічне входить у структуру фінансового ринку, утворюючи його базові складові, але вона не є об'єктивно існуючою соціальною дійсністю. Вона є соціокультурною інтерпретацією позиції дослідника, яка існує у його розумово-пізнавальній діяльності.

Аналізується внутрішній механізм циркуляції грошових потоків і розрахунків на світовому фінансовому ринку, як емпіричній основі дослідження через призму концепції поділу права на приватне та публічне. Проведений аналіз дозволяє зробити висновок, що зазначена концепція не є універсальною. Вона притаманна тільки країнам романогерманської правової системи.

Ідея поділу права на приватне та публічне не знайшла свого відображення на рівні доктрини права у країнах англосаксонської правової системи, на відміну від країн континентальної системи права, для яких такий поділ права є фундаментальним.

За допомогою історичного методу розкривається проблема, яка виникла в радянські часи та пов'язана з підміною понять у доктрині поділу права на приватне та публічне, а також нехтуванням ідеї соціальної справедливості.

Автор привертає увагу до питання, як забезпечити стійкий розвиток фінансової системи та її основних інститутів (структур) за допомогою доктринального підходу поділу права на приватне та публічне. Показано необхідність урахування плюралістичного праворозуміння фінансового ринку як соціального явища. Відповідно методологія дослідження повинна бути максимально адекватною до об'єкта дослідження. Ідея соціальної справедливості має виступати регулятором взаємовідносин між членами суспільства. У зв'язку з тим, що практична діяльність на фінансових ринках різних країн сьогодні має тенденцію до зближення, а також те, що публічне право бере на себе виконання соціальної функції, зроблено висновок про неможливість протиставлення праву публічному права приватного. Право є засобом досягнення суспільного компромісу за умови збереження свободи особи. Саме такий підхід містять у собі європейські політико-правові стандарти у сфері розрахунків.

Ключові слова: фінансова система, ринки фінансових послуг, розрахункові відносини, доктрина поділу права на приватне та публічне.

\section{ВСТуП}

За 30 років незалежності України одним із перспективних напрямів розвитку стають розрахункові відносини. За динамікою росту вони випереджають багато країн Заходу й Азії. Продукти українських фрінтехкомпаній користуються попитом у всьому світі, поповнюють дохідність держбюджету та підвищують фінансову інклюзію українців. I якщо у Незалежність Україна ввійшла фрактично без платіжної інфраструктури та фрінансових технологій, то зараз українська фінтехіндустрія переживає справжній розквіт і продовжує курс на стрімкий розвиток. Правова реальність поступово слідує за відповідними тенденціями. Сучасний розвиток права характеризується пошуком правильних рішень як нових проблем, так і успадкованих від минулого. Домінуючу в континентальній юриспруденції доктрину щодо поділу права на приватне та публічне не можна віднести до категорії нових. На науковому рівні в різних правових системах вона мала свій шлях і вплив на праворозумін- ня. У недавньому минулому вітчизняні правники сконцентрували свою увагу на концепції поділу права на приватне та публічне як методологічному підході для вирішення питань, що виникають на практиці в період становлення законодавчої системи та формування нових цивілізаційних засад після тривалого радянського періоду. Вона стає основою у прагненні створити науку, здатну дати цілісне уявлення про правові і суспільні явища, визначити цілі правового регулювання в умовах формування Україною ринкової економіки, а нові економічні процеси стають емпіричним матеріалом для досліджень. Для формування справедливого економічного порядку увагу привертають дослідження фінансових ринків, процес формування капіталу й розрахунків і на державному рівні, і під час виконання зобов'язань у цивільному обороті. Методологія права повинна забезпечити аналіз конкретних суспільних відносин для підтримання балансу інтересів усіх членів суспільства та надати відповідь на питання: чиї інтереси закріпити у 